\title{
DECLINE AND CURRENT STATUS OF THE GREY PARTRIDGE (PERDIX PERDIX L.) POPULATION IN SERBIA - A REVIEW
}

\author{
Zoran Ristic $^{1 \bullet *}$, Slobodan Puzović ${ }^{2}$, Igor Ponjiger ${ }^{1}$, Miroslav Urošević ${ }^{3}$, Milutin Kovačevićl, \\ Milosava Matejević, ${ }^{\text {, Vladimir Markovićl }}$
}

\begin{abstract}
Summary: Decrease of grey partridge population is a global process that has been catastrophic in recent decades. In England, the number of this species declined by $80 \%$ in the period from the beginning of the fifties to the mideighties of the last century (Potts, 1986). In the Czech Republic from 1965 to the end of the eighties by as much as 95\% (Štasny et al. 1997), and the situation is similar in Poland (Panek, 2005). The status of grey partridge in Serbia follows the same pattern as mentioned, with drastic decline (Ristić and Puzović, 2015). The reasons for such trend are numerous, directly conditioned and are often difficult to eliminate. It has been found that culling has no significant effect on the population (Ristic, 1992), but changes in its habitat in order to increase the yield of agricultural crops and chemical protection have very negative effect on partridge number. In order to study each type of game, it is necessary to know the basic elements of the population: density, growth, birth rate, mortality, migration movements and gender and age structure. Migration has no effect on changes in the partridge populations. Period of assessment 2010-2013: Serbia: 20,000-28,000 breeding pairs (bp), Vojvodina: 900-1,000 bp. Long-term population trend 1980-2003: MD (mean decrease in number), short-term population trend 2000-2013: $M D$ (mean decrease in number).The number generally decreases, especially in Vojvodina, where it is endangered by intensive agriculture and the application of harmful biocides.It is necessary to improve the monitoring and develop the national action plan.
\end{abstract}

Key words: gray partridge, population, protection, Serbia

\section{INTRODUCTION}

Grey partridge (Perdix perdix,Linnaeus 1758) is a wide-spread species in Europe and Western Asia. The overall European population is estimated to be between1.6000-3,100,000 nesting couples or 4,800,000-9,300,000 individual birds, for the period of 1990-2002. In the territory of the Balkan Peninsula and the Pannonian Plain, the estimated density at the end of the $20^{\text {th }}$ century in certain countries is not more than tens of thousands of couples(BirdLifeInternational, 2004).In the territory of Central Europe and the Balkans, the nominal subspecies Perdix perdix perdix Linnaeus, 1758 (Matvejev, 1950) has been registered.

It is believed to be chiefly lowland and highland species although populations with lower density survive also in the mountain habitats. Despite being widespread species and thus having high estimated density, it is seriously endangered due to a drastic density decline in the second half of the $20^{\text {th }}$ century and the first decade of the $21^{\text {st }}$ century (Tucker and Heath, 1994., Hagemeijerand Blair, 1997).It has been included in the international list of endangered species. In 2010, under the Rulebook on Protected and Strictly Protected Species in Serbia, it was classified in the List II for which the season is closed. The grey partridge is widespread throughout Serbia. It is a non-migratory bird with only slight movement of native flocks. In the past few decades, the decline in density in

\footnotetext{
${ }^{1}$ Department for Geography, Tourism, and Hotel Management, Faculty of Sciences, Novi Sad, Serbia

${ }^{2}$ Institute for Nature Conservation of Vojvodina Province, Novi Sad, Serbia

${ }^{3}$ Scientific institute for reproduction and artificial insemination of domestic animals "Temerin", Serbia

•Corresponding author: Zoran Ristić,e-mail: balzakova@yahoo.com ${ }^{*}$ The presented work is part of the research done in scientific project "TR-31084" granted by the Serbian Ministry of Education and Science of the Republic of Serbia
} 
lowland and some hilly regions has been quite noticeable as well as the ever frequent presence of flocks on mountain pastures and barren land. Generally speaking, the density in Serbia is decreasing, especially in Vojvodina where it is adversely affected by intensive farming and agriculture and the use of harmful biocides. After the consideration of the state of affairs and trends, appropriate measures of active protection of isolated flocks and their habitats were proposed

According to Matvejev (1950), in the first half of the $20^{\text {th }}$ century, the grey partridge lived in Serbia throughout lowlands and in the foot of the mountains where there were shrubberies, hedges, groves or weedy fields in the middle of plains and meadows. In such habitats it was most common and not so often it could also be seen on highland pastures. Pekić (1957) emphasises that it is a widespread species in Serbia, primarily in the valleys but that he would occasionally find them in the summer on the mountains higher than 1,800 meters above sea level.

\section{MATERIAL AND METHODS}

In this paper, all available data on the distribution and particularly the density of grey partridge in Serbia since the beginning of the $20^{\text {th }}$ century until the present day have been analysed in order to perceive the population dynamics as realistically as possible and to propose adequate measures for the preservation of the species and its habitats. Published data and information obtained from numerous associates, statistical reports including the data from hunting organisations have been used. The data have been scrutinised carefully and used for assessing the distribution and population dynamics in time and space as well as for determining their trend. Distribution has been presented in overview maps for certain regions and for the entire territory of Serbia. Density in the period 2008-2014 has been estimated for six isolated regions as well as for Serbia in total.

\section{RESULTS}

The total suitable hunting area for grey partridge in Vojvodina at the end of 1980s was 1,923,000 hectares, classified by quality of habitats into 4 prudential categories with density of 4-10 individual birds per 100 hectares (Ristić, 1989). It disappeared or is on the verge of disappearance on many sites in Vojvodina in the first decade of the $21^{\text {st }}$ century. Out of 59 hunting sites in total, it almost disappeared in 24 of them, with only small and isolated flocks of not more than 10-20 individual birds remaining. Somewhat higher density is still present in Srem and some parts of Banat, while it is the lowest in Bačka (Beuković et al. 2000; Lovački savez Srbije, 2001). 


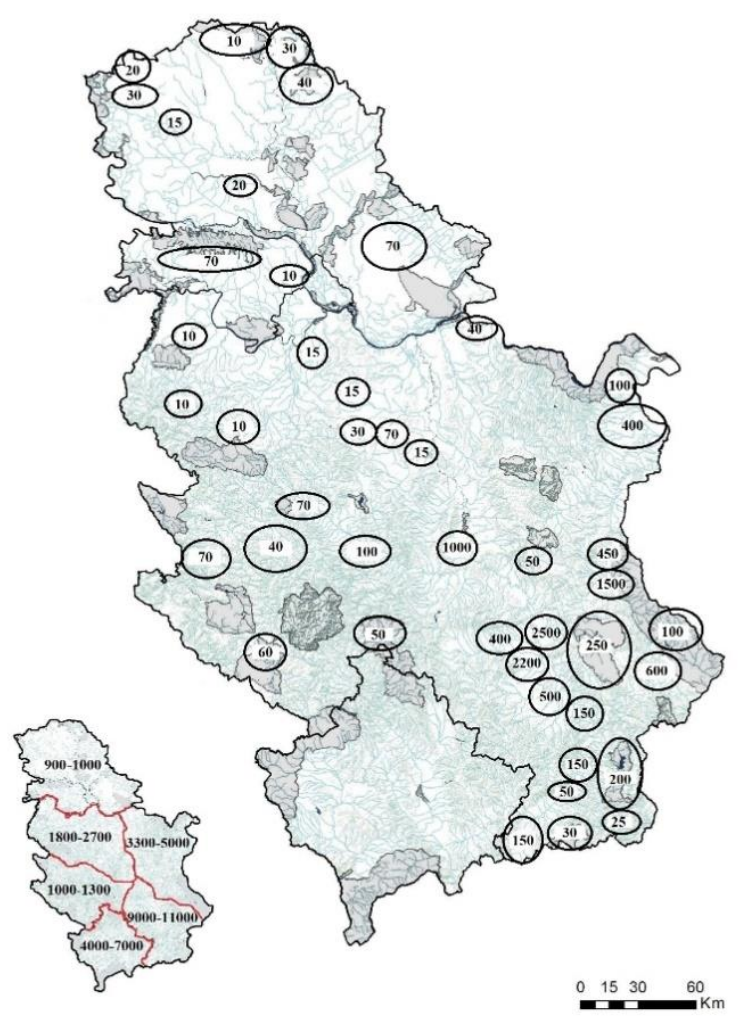

Figure 1. Estimates of the number of nesting couples in isolated areas (large map) and in six isolated regions (small map) in Serbia in the period of 2008-2014

The situation is somewhat better in Central Serbia and it is estimated that out of 154 hunting sites, in about 120 of them this species survives in certain number which is still not critically low. It is most widespread nowadays in the valley and hills of the Južna Morava, as well as in some parts of the Velika Morava basin. The best habitats are located in the areas in the vicinity of Niš, Prokuplje, Žitorađa, Blace, Doljevac, Belušić, Kalenić, Leskovac, Vranje, Bujanovac. It is very present and numerous in some mountainous regions around the Vlasina. Present distribution and the population density in Kosovo and Metohija are unknown.

Monitoring and estimation of grey partridge population initiated in the second half of the $20^{\text {th }}$ century (since mid-1960s) was organised in Serbia, chiefly within hunting organisations in Vojvodina. The first "official" data on the culling of birds in Serbia were made for the period of 1904-1909 and 1929-1930 (Marinović, 1930). For the first half of the $20^{\text {th }}$ century Matvejev (1950) stated that the density of grey partridge varied a lot during the years, that in some areas it seemingly disappeared only to re-appear again after a few years and become abundant. He related this to many factors, primarily to the duration of snow cover and frosty days, hunting pressure, use of chemicals in agriculture etc. 


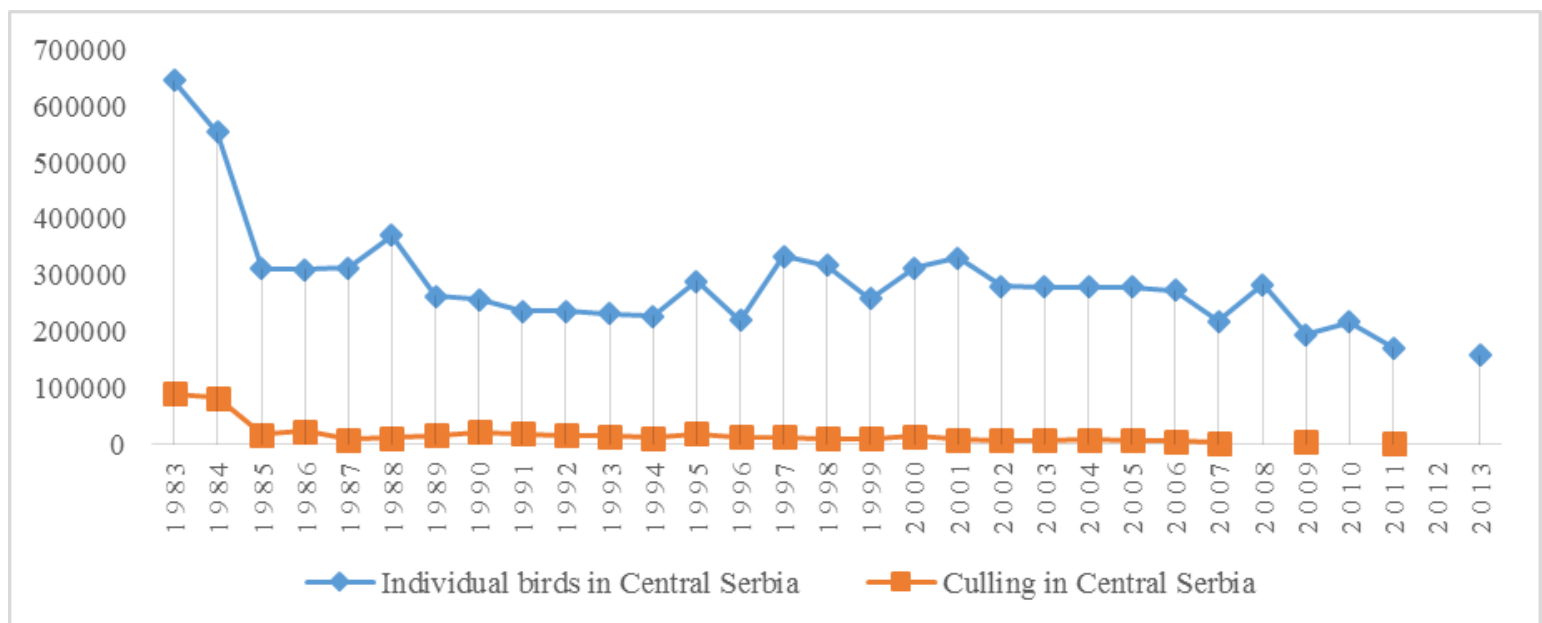

Chart 1. Numerical strength and culling of grey partridge (Perdixperdix) in Central Serbia (1983-2013) expressed in individual birds, according to the hunting statistics of Hunting association of Serbia

Due to the decline in density in Serbia after the Second World War, especially during the 1950s, in 1959 a Decision on a Five-Year Ban on Hunting was enacted, which gave positive results through the recovery of population in the mid-1960s and its growth until the mid-1970s, along with the prescribed additional measures (capturing for the purpose of grounding, artificial farming and settlement, reduction of predators). Afterwards, consecutive snowy and cold winters followed as well as the intensification of agriculture (land parcelling, removal of boundaries and uncultivated land, pesticides) which led to a drastic fall in the number of birds during the 1980s.

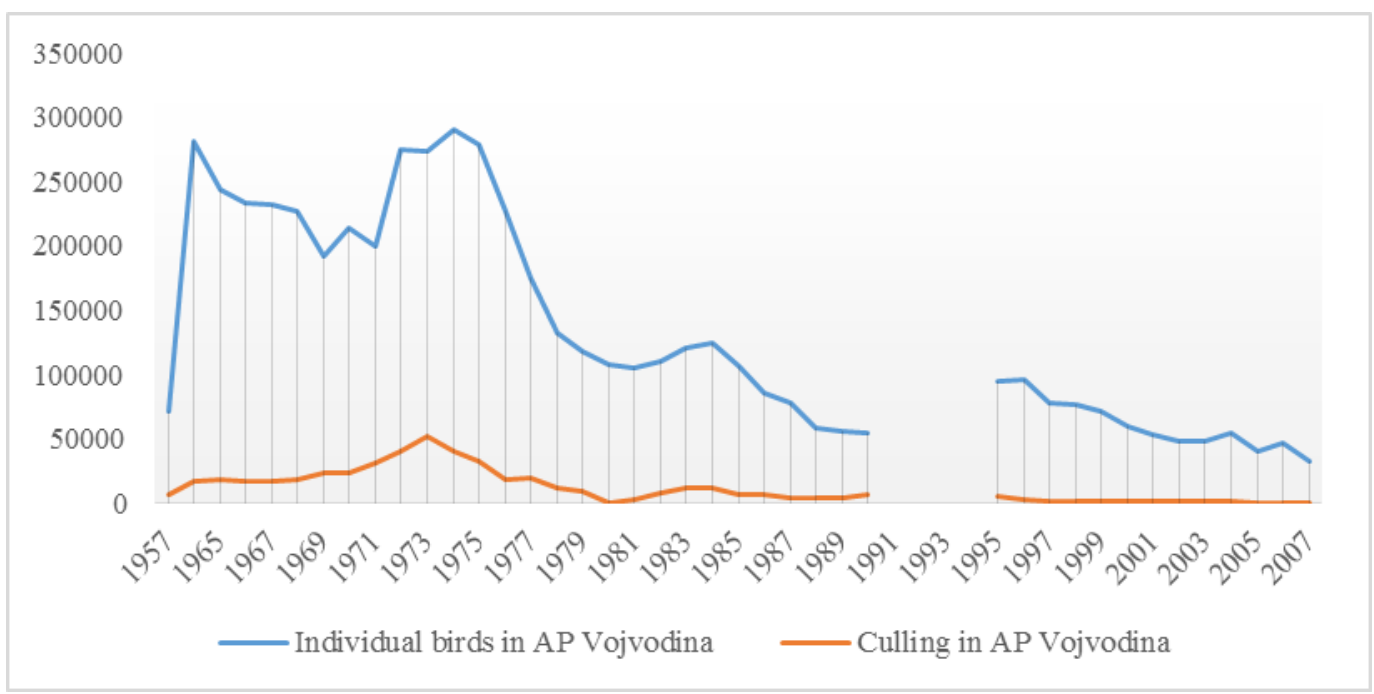

Chart 2. : Numerical strength and culling of grey partridge (Perdixperdix) in the AP Vojvodina (1957-2007) expressed in individual birds, according to the hunting statistics of the Hunting Association of Vojvodina

The record year in terms of density but also in the culling of grey partridge in Vojvodina was 1974 after which the decline in density of over $50 \%$ by 1983 was registered (Ristić, 1989). The average spring density in Serbia during the 1970s was over 20 individual birds per 100 hectares and in the late $1990 \mathrm{~s}$, there were only $1-2$ couples per $1 \mathrm{~km}^{2}$. In Vojvodina, this density amounted to 15.05 individual birds per $\mathrm{km}^{2}$ during this best assessed year of 1974 (Šelmić et al. 1977).

\section{DISCUSSION}

Preservation of endangered population of grey partridge in Serbia is closely related to the knowledge of its actual distribution, density, dynamics of areals and population, as well as requirements for habitat conditions and feeding, impact of predators and chemicals used in agriculture and abiotic factors, particularly in the winter period. 
For the second half of the $20^{\text {th }}$ century and the beginning of the $21^{\text {st }}$ century, Ristic (2008) emphasises that it primarily settles in Vojvodina and other lowland areas of Serbia but that it can also be seen in the hilly and mountainous areas and it is not unusual to find smaller flocks on the highland pastures of the Suva Planina, the StaraPlanina, the Vardenik, the Vlasina, the Kopaonik, the Prokletije and the Šar-Planina, higher than 1,500 above sea level. It used to be rather common in Kosovo and Metohija in 1950s and 1960s, especially in Kosovo Polje, Malo Kosovo, Lješani, in Metohija and Drenica (Marčetić and Andrejević, 1960; Pekić, 1957; Šaranović, 1967).

There is certain cyclicality in the dynamics of the grey partridge population in certain intervals which was detected in some parts of Serbia (Matvejev, 1950; Pekić, 1957: Ristić, 1989; Lovački savez Srbije, 2001). In Vojvodina, cycles vary from 11-12 years. The maximum values for those cycles in time reached ever smaller values for the number of individual birds and couples, with smaller ranges between the minimum and maximum density (Ristić, 1989;Lovački savez Srbije, 2001).

According to Chart 1, the periods of highest density in the territory of Serbia were recorded during 1983-84; 1988; 1997-98; 2000-01; and 2008.Analysing Chart 2 it can be seen that in Vojvodina the periods of highest density were during 1964-67; 1972-75; 1980; 1983-84; 1993-96. According to the hunting statistics, the density in Serbia in the period of 1990-2007, ranged between 200,000 and 300,000 individual birds, and the culling of birds ranged from 5,000 to 21,000 individual birds per year. Due to the extreme decline in the density in some parts of Serbia, the Decision on the Abandonment of the Hunting Season in the period of 2012-2015 was enacted.

The estimation of nesting density of grey partridge in Serbia was organised within the BirdLife International Programme (BLI), under the coordination of the Serbian Society for the Protection and Study of Birds.The first estimate (BiE2) was conducted for the period of 1990-2002, when it was estimated that there were 25,000 - 45,000 nesting couples on average in the territory of Serbia per year or 75,000 individual birds at the beginning of autumn. There were 10,000 - 15,000 nesting couples in Vojvodina and 5,000 - 10,000 in Kosovo and Metohija, while there were 10,000 - 20,000 of them in Central Serbia (Puzović et al. 2003).

The second estimate (BiE3) was conducted for the period of 2008 - 2013, when it was estimated that there were $20,000-28,000$ nesting couples on average in the territory of Serbia per year or 60,000 - 84,000 individual birds at the beginning of autumn. In Vojvodina, there were as few as 900 - 1,000 nesting couples, 4,000 - 7,000 in Kosovo and Metohija, and15,000 - 20,000 in Central Serbia (Puzović et al. 2014).

When average annual estimates of density within the BLI programme and hunting statistical data are compared, we can generally conclude that the estimates of hunting organisations are 2 to 2.5 times greater so they should be taken into consideration cautiously.

It is necessary to improve the conditions for the survival of the grey partridge in their habitats (building coverts, ban on the burning of vegetation debris, proper winter feeding). It is also important to encourage the use of installed scare devices on lawn mowers and to conduct serious control of the use of harmful chemicals in agriculture along with the reduction of predators and fight for the preservation of coverts, boundaries, uncultivated and weedy land as well as rangeland within agricultural areas in order to improve the conditions for feeding, reproduction, hiding and wintering in particular.

\section{CONCLUSION}

In the past few decades, a noticeable decline in the density in lowlands and some highland areas has been detected as well as the more frequent presence of flocks on mountain pastures and barren land. The density in Serbia in the past decades has been decimated and is less than one third of the population from the 1970s. The best habitats are located in the valleys of the Velika Morava and the Južna Morava.The most influential endangering factors are intensive agriculture and use of harmful biocides. The population trend was described as drastically declining. It is necessary to improve the monitoring and develop the national action plan.

\section{REFERENCES}

BIRDLIFE INTERNATIONAL (BLI): Birds in Europe: population estimates, trends and conservation status. Cambridge, BLI Series No.12, 2004.

BIRDLIFE INTERNATIONAL: Species factsheet: Perdix perdix. 2015.

BEUKOVIĆ, M., ŠELMIĆ, V., JOVIĆ, D., VAPA, M., PUZOVIĆ, S., PANTELIĆ, A., BOGNAR, M., NOVKOV, M., ĐAKOVIĆ, D., ZEREMSKI, M.: Dugoročni program razvoja lovstva Vojvodine 2000-2010. godine. Lovački savez Vojvodine, Novi Sad, 119pp, 2000.

HAGEMEIJER W. G. M., BLAIR M. J.: The EBCC Atlas of European Breeding Birds, Their Distribution and Abundance - T. and A. D. Poyser, London, 1997.

LOVAČKI SAVEZ SRBIJE: Program razvoja lovstva Srbije 2001-2010. Beograd, 241 pp, 2001.

MARČETIĆ, M., ANDREJEVIĆ, D.: Ornitofauna Kosova i Metohije. Rilindija, Priština, 116 pp, 1960. 
MARINOVIĆ, M.,: Privredni značaj lova u Jugoslaviji. Štamparija Privredni pregled. Beograd, 219 pp, 1930.

MATVEJEV, SERGEJ D.: Rasprostranjenje i život ptica u Srbiji, Beograd: Naučna knjiga, 1950.

PANEK, M.: Demography of grey partridges Perdix perdix in Poland in the years 1991-2004: reasons of population decline. Eur. J. Wildl. Res. 51: 14-18. 7, 2005.

PEKIĆ, B.: Uzroci opadanja brojnosti poljske jarebice na Kosovu i Metohiji u pojedinim godinama. Lovac, Beograd, 3: 68-69, 1957.

PUZOVIĆ, S., SIMIĆ, D., SAVElJIĆ, D., GERGElJ, J., TUCAKOV, M., STOJNIĆ, N., HULO,I., HAM, I., VIZI, O., ŠĆIBAN, M., RUŽIĆ, M., VUČANOVIĆ, M. \& JOVANOVIĆ, T.: Ptice Srbije i Crne gore - veličine gnezdilišnih populacija i trendovi - 1990-2002. Ciconia, Novi Sad, 12:35-129, 2003.

PUZOVIĆ, S., RADIŠIĆ, D., RUŽIĆ, M., RAJKOVIĆ, D., RADAKOVIĆ, M., PANTOVIĆ, U., JANKOVIĆ, M., STOJNIĆ, N., ŠĆIBAN, M., TUCAKOV, M., GERGELJ, J., SEKUliĆ, G., AGOŠTON, A. \& RAKOVIĆ, M.: Ptice Srbije - veličine gnezdilišnih populacija I trendovi - 2008-2014. DZPPS, posebno izdanje, NoviSad, 2014.

POTTS, G. R.: The Partridge: Pesticides, predation and conservation. London: Collins, 1986.

RISTIĆ, Z.: Poljska jarebica (Perdixperdix) gajenje i gazdovanje. Lovačke novine, Novi Sad, 6:15-16, 1989.

RISTIĆ, Z.: Elementi dinamike populacije poljske jarebice (Perdix perdix L. ) u Vojvodini kao osnov za određivanje stepena racionalnog korišćenja. Lovačke novine, NoviSad, 7-8:10-11; 9-10:12-13, 1992.

RISTIĆ, Z., PUZOVIĆ S.: Gospodarenje poljskom jarebicom (Perdix perdix L.) u Vojvodini, Zbornik priopćenja - abstrakata sa 2. znanstveno stručnog skupa održanog u Vukovaru 15. aprila 2015. godine, str. 19 i 20, ISBN 978-953-7871-43-7; Izdavač: Vukovarsko - srijemska županija, Poljoprivredni fakultet u Osijeku, 2015.

TUCKER G. M., HEATH M.F.: Birds in Europe: their conservation status - Birdlife Conservation Series 3, Cambridge, 1994.

ŠARANOVIĆ, P.: Poljska jarebica u lovištima Kosmeta. Lovačke novine, Novi Sad, 4 (117): 5, 1967.

ŠELMIĆ V., ČORDA A., ALEKSIĆ D.: Mere zaštite i uzgoja divljači u Dugoročnom programu razvoja lovstva u Vojvodini, Priroda Vojvodine III/2, Novi Sad, 1977.

ŠTASNY, K., BEJČEK, V., HUDEC, K.: Atlas hnizdniho razšireni ptaku v Českerepublice 1985 - 1989. H\&H, Jinočany, 1997.

\title{
SMANJENJE BROJNOSTI I TRENUTNI STATUS POPULACIJE POLJSKE JAREBICE (PERDIX PERDIX) U SRBIJI
}

\author{
Zoran Ristić, Slobodan Puzović, Igor Ponjiger, Miroslav Urošević, Milutin Kovačević, \\ Milosava Matejević, Vladimir Marković
}

\begin{abstract}
Rezime: Ugroženost i smanjenje brojog stanja poljskih jarebica (Perdix perdix L.) je globalni proces koji u zadnjih nekoliko decenija dobija katastrofalne razmere. U Engleskoj se brojnost ove vrste u periodu od početka pedesetih do sredine osamdesetih godina prošlog veka smanjila za 80 \% (Potts, 1986), u Češkoj Republici od 1965. do kraja osamdesetih za čak $95 \%$ (Śtasny i sar. 1997), a slično je stanje i u Poljskoj (Panek, 2005), a skoro da je ista situacija i u Srbiji (Ristić i Puzović, 2015). Razloga za takav trend ima više, neposredno uslovljenih i najčešće teško mogu da se eliminišu. Njeno iskorišćavanje dokazano je da ne utiče bitno na brojnost (Ristić, 1992), ali promene u njenom staništu u cilju povećanja prinosa poljoprivrednih kultura koje se na njima gaje i hemijska zaštita sa druge strane su veoma negativno uticale na njenu brojnost. Da bi se proučavala svake vrste divljači neophodna je poznavanje osnovnih elemenata populacione: gustina; prirasta, natalitet, mortalitet i migraciona kretanja i polna $i$ starosna strukture. Migracija, kod jarebica je dokazano da su verne staništu, nema nikakvog uticaja na promene u gustinama njenih populacija. Period procene 2010-2013: Srbija: 20.000-28.000 gnezdećih parova (gp), Vojvodina: 900-1.000 gp. Dugoročni trend populacije 1980-2003: MD (srednje opadanje brojnosti), kratkoročni trend populacije 2000-2013: MD (srednje opadanje brojnosti). Brojnost generalno opada, posebno u Vojvodini gde je ugrožava intezivna poljoprivreda $i$ primena štetnih biocida. Neophodno je poboljšati monitoring vrste $i$ razviti nacionalni akcioni plan.
\end{abstract}

Ključne reči: poljska jarebica, populacija, zaštita, Srbija

Received / Primljen: 28.12.2017. Accepted / Prihvaćen: 11.05.2018. 